\title{
Citric Acid Production by Yarrowia lipolytica Yeast on Different Renewable Raw Materials
}

\author{
Igor G. Morgunov *, Svetlana V. Kamzolova (iD) and Julia N. Lunina
}

G.K. Skryabin Institute of Biochemistry and Physiology of Microorganisms, Russian Academy of Sciences, pr-t Nauki, 5, 142290 Pushchino, Russia; kamzolova@rambler.ru (S.V.K.); luninaj@rambler.ru (J.N.L.)

* Correspondence: morgunovs@rambler.ru

Received: 28 April 2018; Accepted: 15 May 2018; Published: 17 May 2018

\begin{abstract}
The world market of citric acid (CA) is one of the largest and fastest growing markets in the biotechnological industry. Microbiological processes for CA production have usually used the mycelial fungi Aspergillus niger as a producer and molasses as a carbon source. In this paper, we propose methods for CA production from renewable carbon substrates (rapeseed oil, glucose, glycerol, ethanol, glycerol-containing waste of biodiesel industry and glucose-containing aspen waste) by the mutant strain Yarrowia lipolytica NG40/UV5. It was revealed that Y. lipolytica grew and synthesized CA using all tested raw materials. The obtained results are sufficient for industrial use of most of the raw materials studied for CA production. Using rapeseed oil, ethanol and raw glycerol (which is an important feedstock of biodiesel production), a high CA production (100-140 $\mathrm{g} \mathrm{L}^{-1}$ ) was achieved.
\end{abstract}

Keywords: yeast Yarrowia lipolytica; citric acid (CA) production; raw materials

\section{Introduction}

Citric acid (CA) and its salts are widely used as an acidulate, flavoring agent and antioxidant in the production of beverages and confectionery, in infant formula, as well as in the chemical, pharmaceutical, electronic, defense, and other industries. The volume of citric acid globally exceeds two million tons per year and its production is annually increased by $5 \%$ [1].

Modern technologies of citric acid (CA) production are based on using various mutant strains of the mycelial fungi Aspergillus niger as a producer and molasses as a raw material. CA production by fungi is a complicated and environmentally unsafe process; as a result of its implementation, a large number of both liquid effluents containing mineral acids, ballast organic substances, cyanides, and solid wastes, primarily gypsum, are accumulated. Moreover, $A$. niger is an opportunistic pathogenic fungi and can cause allergic diseases and aspergillosis [2,3].

Over the past 40 years, the interest of researchers has focused on yeast as a producer of CA; the yeast Yarrowia lipolytica has been the most used CA producer [1-3]. Initially, this kind of yeast attracted the attention of researchers due to its ability to grow and synthesize CA in media with $\mathrm{n}$ alkanes-an available and cheap substrate [2]. However, due to changes in the world oil market, the use of this substrate has become economically unprofitable. In this regard, it is of interest to use other types of raw materials.

The choice of raw materials for developing CA biotechnology is determined by factors such as renewability, ability of the producer to assimilate the substrate with a high conversion rate, consumption value and cost price of the target product. To carry out fermentation processes, in addition to very expensive food raw materials, such as glucose [4-7] and plant oils [8-10], much cheaper substrates which are waste products of various industries, such as glycerol-containing waste of the biodiesel industry [9-17], glucose-containing wood hydrolysates [18,19], olive mill waste-water [20], 
and inulin [21] are used. Ethanol, a water-soluble individual compound which ensures the formation of a pure product and facilitates the isolation process, is also of great importance [22,23]. In the works of the above-mentioned researchers it was shown that all these substrates are promising for CA production and the use of glycerol-containing waste of biodiesel industry and glucose-containing wood hydrolyzates can increase the profitability of CA production process.

The aim of this work was a comparative study of CA production by the yeast Y. lipolytica on different types of renewable raw materials.

\section{Materials and Methods}

\subsection{Microorganisms and Chemicals}

The mutant strain Y. lipolytica NG40/UV5 was obtained as described previously [9,24].

Chemicals, the manufacturer of the carbon sources, and their characteristics were presented in our published articles $[7,9,15,17]$.

\subsection{Media and Cultivation Conditions}

All experiments were done using the same equipment, nutrient medium and cultivation conditions. Strain Y. lipolytica NG40/UV5 was cultivated in a 10-L ANKUM-2M fermenter (Pushchino, Russia) with an initial volume of $5 \mathrm{~L}$. The medium contained $\left(\mathrm{g} \mathrm{L}^{-1}\right)$ : carbon source: $\left(\mathrm{NH}_{4}\right)_{2} \mathrm{SO}_{4}$, 6; $\mathrm{MgSO}_{4} \cdot 7 \mathrm{H}_{2} \mathrm{O}, 1.4 ; \mathrm{NaCl}, 0.5 ; \mathrm{Ca}\left(\mathrm{NO}_{3}\right)_{2}, 0.8 ; \mathrm{KH}_{2} \mathrm{PO}_{4}, 2.0 ; \mathrm{K}_{2} \mathrm{HPO}_{4}, 0.2 ;$ Difco yeast extract (BD Diagnostic Systems, Sparks, MD, USA), 1.0; trace elements (mg L ${ }^{-1}$ ): $\mathrm{FeSO}_{4} \times 7 \mathrm{H}_{2} \mathrm{O}, 14.9 ; \mathrm{MnSO}_{4} \times$ $4 \mathrm{H}_{2} \mathrm{O}, 0.2 ; \mathrm{ZnSO}_{4} \times 7 \mathrm{H}_{2} \mathrm{O}, 8.1 ; \mathrm{CuSO}_{4} \times 5 \mathrm{H}_{2} \mathrm{O}, 3.9$. The fermentation conditions were maintained automatically at a constant level: Temperature $28-0.5^{\circ} \mathrm{C} ; \mathrm{pH} 4.5 .0-0.1 ; \mathrm{pO}_{2} 50 \%$ (of air saturation); agitation rate of $800 \mathrm{rpm}$. Pulsed addition of carbon source (by 2-20 g L ${ }^{-1}$ ) depending on the carbon source used was performed as the $\mathrm{pO}_{2}$ value changed by $10 \%$. Cultivation was continued for 6 days.

\subsection{Assays}

Biomass, concentration of CA, isocitric acid (ICA) and other organic acids were determined as described previously [7].

\subsection{Calculations}

Earlier, it was found that the mass yield of CA production $\left(\mathrm{Y}_{\mathrm{CA}}\right)$, expressed in $\mathrm{g}$ of CA per $\mathrm{g}$ of carbon source, and the fermenter productivity, expressed in $\mathrm{g}(\mathrm{L} \cdot \mathrm{h})^{-1}$ were influenced by the medium dilution due to the addition of $\mathrm{NaOH}$ solution for maintaining a constant $\mathrm{pH}$ value $[9,17]$. In this regard, the total amount of $\mathrm{CA}$ in the culture broth at the end of the fermentation was used to calculate $\mathrm{Y}_{\mathrm{CA}}$ and fermenter productivity. Formulas for calculation of $\mathrm{Y}_{\mathrm{CA}}$ value and fermenter productivity were described earlier $[9,17]$.

All the data presented are the mean values of three experiments and two measurements for each experiment; standard deviations were calculated (S.D. $<10 \%$ ).

\section{Results and Discussion}

The dynamics of nitrogen consumption and the accumulation of biomass and CA by Y. lipolytica NG40/UV5 grown on rapeseed oil are shown in Figure 1a, while the logarithmic growth curve $(\mu)$ and the specific rate of biosynthesis of CA $\left(q_{p}\right)$ are shown in Figure $1 \mathrm{~b}$. As it can be seen in the latter figure, the growth curve had an exponential phase (phase I) lasting for $12 \mathrm{~h}$, growth retardation phase (phase II) lasting from 12 to $36 \mathrm{~h}$ of cultivation, and stationary phase (phase III) lasting from $36 \mathrm{~h}$ to the end of cultivation. The retardation of growth coincided with the exhaustion of nitrogen from the medium. The specific growth rate attained a maximum $\left(\mu_{\max }=0.360 \mathrm{~h}^{-1}\right)$ in the exponential growth phase (12 $\mathrm{h}$ of cultivation). This value of $\mu$ max was more than two times higher than that of the other CA-producing strain Y. lipolytica $\left(0.17-0.22 \mathrm{~h}^{-1}\right)$ [4,8]. After $12 \mathrm{~h}$ of cultivation, $\mu$ gradually decreased 
to zero after $48 \mathrm{~h}$ of cultivation. The excretion of CA did not occur in the exponential growth phase but became active in the growth retardation and stationary phases. Within this cultivation period, the specific rate of CA production $\left(\mathrm{q}_{\mathrm{p}}\right)$ was between 0.065 and $0.104 \mathrm{~g} \mathrm{CA} / \mathrm{g} \cdot \mathrm{h}$. At the end of cultivation $\left(144 \mathrm{~h}\right.$ ), the strain produced $140 \mathrm{~g} \mathrm{~L}^{-1} \mathrm{CA}$ and $5.3 \mathrm{~g} \mathrm{~L}^{-1} \mathrm{ICA}$ (data not shown) with CA:ICA ratio of 26.4:1. The CA production yield $\mathrm{Y}_{\mathrm{CA}}$ was $1.5 \mathrm{~g} \mathrm{~g}^{-1}$; the fermenter productivity was calculated to be $1.46 \mathrm{~g}(\mathrm{~L} \cdot \mathrm{h})^{-1}$ with account for the dilution factor.
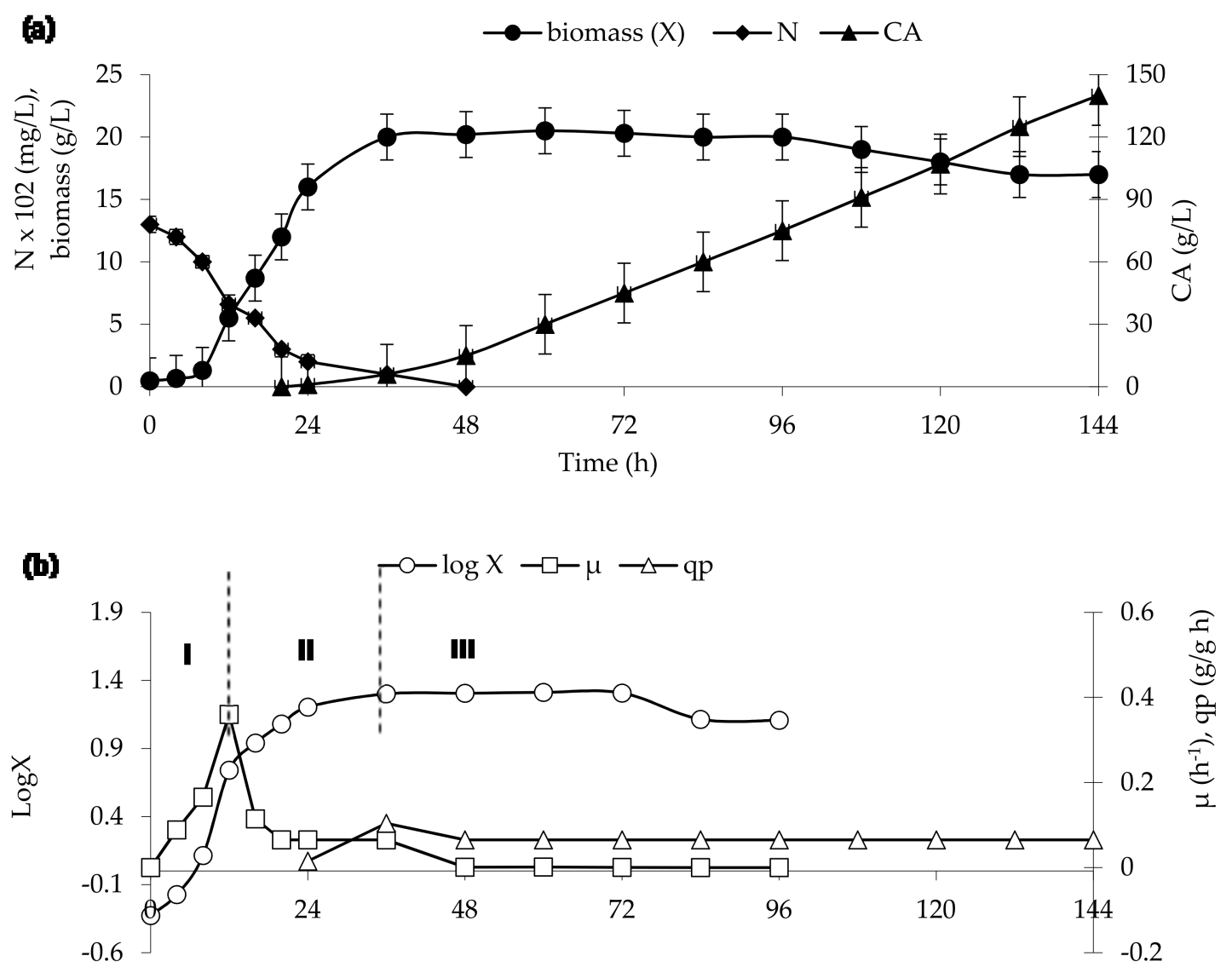

Time (h)

Figure 1. Time courses of nitrogen consumption, biomass accumulation, and citric acid production in Y. lipolytica grown on rapeseed oil (a) and calculated parameters of the process (b): I-the exponential cell growth; II-the cell growth retardation; III-the stationary phase.

The data of the accumulation of biomass and CA by Y. lipolytica NG40/UV5 grown on other substrates compared to rapeseed oil are shown in Table 1.

Table 1. Citric acid production by Y. lipolytica on various carbon sources.

\begin{tabular}{|c|c|c|c|c|c|c|}
\hline Substrates & $\begin{array}{c}\text { Biomass } \\
\left(\mathrm{g} \mathrm{L}^{-1}\right)\end{array}$ & $\begin{array}{c}\mathrm{CA} \\
\left(\mathrm{g} \mathrm{L}^{-1}\right)\end{array}$ & $\begin{array}{c}\text { ICA } \\
\left(\mathrm{g} \mathrm{L}^{-1}\right)\end{array}$ & CA:ICA & $\begin{array}{l}\text { Productivity } \\
\left(\mathrm{g}(\mathrm{L} \cdot \mathrm{h})^{-1}\right)\end{array}$ & $\underset{\left(\mathrm{g} \mathrm{g}^{-1}\right)}{\mathrm{Y}_{\mathrm{CA}}}$ \\
\hline Rapeseed oil & $17.0 \pm 1.1$ & $140.0 \pm 5.0$ & $5.3 \pm 0.8$ & 26.2:1 & 1.46 & 1.50 \\
\hline Glucose & $18.7 \pm 1.3$ & $100.8 \pm 9.2$ & $4.9 \pm 0.9$ & $20.6: 1$ & 1.05 & 0.80 \\
\hline Glycerol & $16.8 \pm 1.1$ & $87 \pm 6.4$ & $13 \pm 1.1$ & $6.7: 1$ & 0.906 & 0.64 \\
\hline Glycerol waste of biodiesel industry & $20.0 \pm 1.8$ & $100 \pm 3.4$ & $15 \pm 1.2$ & $7.7: 1$ & 1.04 & 0.90 \\
\hline Ethanol & $15.3 \pm 1.4$ & $106.7 \pm 2.7$ & $15 \pm 1.4$ & 7.1:1 & 1.32 & 0.87 \\
\hline
\end{tabular}


As seen in Table 1, at the end of cultivation (144 h), Y. lipolytica NG40/UV5 produced $100.8 \mathrm{~g} \mathrm{~L}^{-1} \mathrm{CA}$ and $4.9 \mathrm{~g} \mathrm{~L}^{-1}$ ICA with CA:ICA ratio of 20.6:1 in the medium containing glucose. The CA production yield $\mathrm{Y}_{\mathrm{CA}}$ was $0.80 \mathrm{~g} \mathrm{~g}^{-1}$; the fermenter productivity was calculated to be $1.05 \mathrm{~g}(\mathrm{~L} \cdot \mathrm{h})^{-1}$.

As seen in Table 1, Y. lipolytica NG40/UV5 only produced $31.2 \mathrm{~g} \mathrm{~L}^{-1} \mathrm{CA}$ and $7.84 \mathrm{~g} \mathrm{~L}^{-1}$ ICA with CA:ICA ratio of $4: 1$ in the medium containing glucose-containing aspen waste. The CA production yield $\mathrm{Y}_{\mathrm{CA}}$ was $0.50 \mathrm{~g} \mathrm{~g}^{-1}$; the fermenter productivity was calculated to be $0.325 \mathrm{~g}(\mathrm{~L} \cdot \mathrm{h})^{-1}$.

As it can be seen from the data in Table 1, the mutant grows perfectly and synthesizes CA both in a medium with pure glycerol and in a medium with biodiesel-derived glycerol. Y. lipolytica NG40/UV5 produced $87 \mathrm{~g} \mathrm{~L}^{-1} \mathrm{CA}$ with a ratio of CA to ICA of 6.7:1. The application of waste glycerol for Y. lipolytica NG40/UV5 cultivation increased CA production by $15 \%$ (up to $100 \mathrm{~g} \mathrm{~L}^{-1}$ ) compared to that obtained from pure glycerol; the CA to ICA ratio was 7.7:1. The fermenter productivity was high and reached 0.906 and $1.04\left(\mathrm{~g}(\mathrm{~L} \cdot \mathrm{h})^{-1}\right)$ in the media with pure- and biodiesel-derived glycerol, respectively. The mass yield $\left(\mathrm{Y}_{\mathrm{CA}}\right)$ reached 0.64 and $0.9 \mathrm{~g} / \mathrm{g}$ in the media with pure- and biodiesel-derived glycerol, respectively.

As seen in Table 1, Y. lipolytica NG40/UV5 produced $106.7 \mathrm{~g} \mathrm{~L}^{-1} \mathrm{CA}$ and $15 \mathrm{~g} \mathrm{~L}^{-1} \mathrm{ICA}_{\text {with }}$ CA:ICA ratio of 7.1:1 in the medium containing ethanol. The CA production yield $\mathrm{Y}_{\mathrm{CA}}$ was $0.87 \mathrm{~g} \mathrm{~g}^{-1}$; the fermenter productivity was calculated to be $1.32 \mathrm{~g} / \mathrm{L} \cdot \mathrm{h}$.

Comparative data on the most efficient processes of CA production by yeasts Y. lipolytica from various carbohydrate-containing substrates are given in Table 2. As seen in this table, in the experiments with wild and mutant strains, Y. lipolytica produced CA in industrially sufficient amounts. For instance, in the mutant strain Saccharomycopsis lipolytica NTG9 grown on rapeseed oil, the CA concentration reached $152.3 \mathrm{~g} \mathrm{~L}^{-1}$ with the yield ( $\left.\mathrm{Y}_{\mathrm{CA}}\right)$ of $1.5 \mathrm{~g} \mathrm{~g}^{-1}$ [25]. Aurich et al. [26] obtained a CA concentration of $198 \mathrm{~g} \mathrm{~L}^{-1}$ with the yield ( $\mathrm{Y}_{\mathrm{CA}}$ ) of $1.16 \mathrm{~g} \mathrm{~g}^{-1}$, which was achieved after a $300 \mathrm{~h}$ fed-batch cultivation of the wild strain Y. lipolytica H181. The wild strains Y. lipolytica H222 and Y. lipolytica W29, grown on glucose, produced $41 \mathrm{~g} \mathrm{~L}^{-1}$ [4] and $49 \mathrm{~g} \mathrm{~L}^{-1}$ of CA, respectively [27]. Recently, we found that the wild strain Y. lipolytica VKM Y 2373, cultivated in a medium with glucose under cell growth limitation using nitrogen, phosphorus and sulfur, produced CA at a level of $80-85 \mathrm{~g} \mathrm{~L}^{-1}$ with a yield of $0.70-0.75 \mathrm{~g} \mathrm{~g}^{-1}$ [7]. The overexpression of gene PYR encoding pyruvate carboxylase in Y. lipolytica, resulted in the production of CA at a level of 95-111.1 $\mathrm{g} \mathrm{L}^{-1}$ with the yield ( $\left.\mathrm{Y}_{\mathrm{CA}}\right)$ of $0.75-0.93 \mathrm{~g} \mathrm{~g}^{-1}[5,6]$. Strain Y. lipolytica ACA-DS 50109 cultivated on glucose and olive mill wastewaters produced CA (28.9 $\mathrm{g} \mathrm{L}^{-1}$ ) with the product yield $\left(\mathrm{Y}_{\mathrm{CA}}\right)$ of $0.53 \mathrm{~g} \mathrm{~g}^{-1}$ [28]. Later, the authors of the last article improved the process of CA production up to $52.0 \mathrm{~g} \mathrm{~L}^{-1}$ with the product yield ( $\mathrm{Y}_{\mathrm{CA}}$ ) of $0.64 \mathrm{~g} \mathrm{~g}^{-1}$ using strain Y. lipolytica ACA-YC 5033, which was also able to remove harmful phenolic compounds from olive mill wastewaters [29]. The glycerol-grown yeast Y. lipolytica NRRL YB-423 produced $21.6 \mathrm{~g} \mathrm{~L}^{-1}$ of CA with mass yield of $0.54 \mathrm{~g} \mathrm{~g}^{-1}$ [12]; strain Y. lipolytica ACA-DC 50109 synthesized $62.5 \mathrm{~g} \mathrm{~L}^{-1}$ of CA with mass yield of $0.56 \mathrm{~g} \mathrm{~g}^{-1}$ from raw glycerol [20], while the recombinant strain Y. lipolytica NCYC3825 was able to produce $58 \mathrm{~g} \mathrm{~L}^{-1}$ of CA [30]. Earlier, we indicated that the other mutant Y. lipolytica NG40/UV7 synthesized, CA $\left(122.2 \mathrm{~g} \mathrm{~L}^{-1}\right)$ with the yield of $0.95 \mathrm{~g} \mathrm{~g}^{-1}$. The high CA production (up to $140 \mathrm{~g} \mathrm{~L}^{-1}$ ) has also been reported for acetate-negative mutant Y. lipolytica Wratislavia AWG7, grown on crude glycerol [13] and recombinant strain Y. lipolytica H222-S4 (p67ICL1), harboring the invertase encoding ScSUC2 gene of Saccharomyces cerevisiae under inducible XPR2 promoter control and multiple ICL1 copies, cultivated on sucrose [31]. 
Table 2. Comparative data of the processes of CA production from various substrates using Y. lipolytica strains.

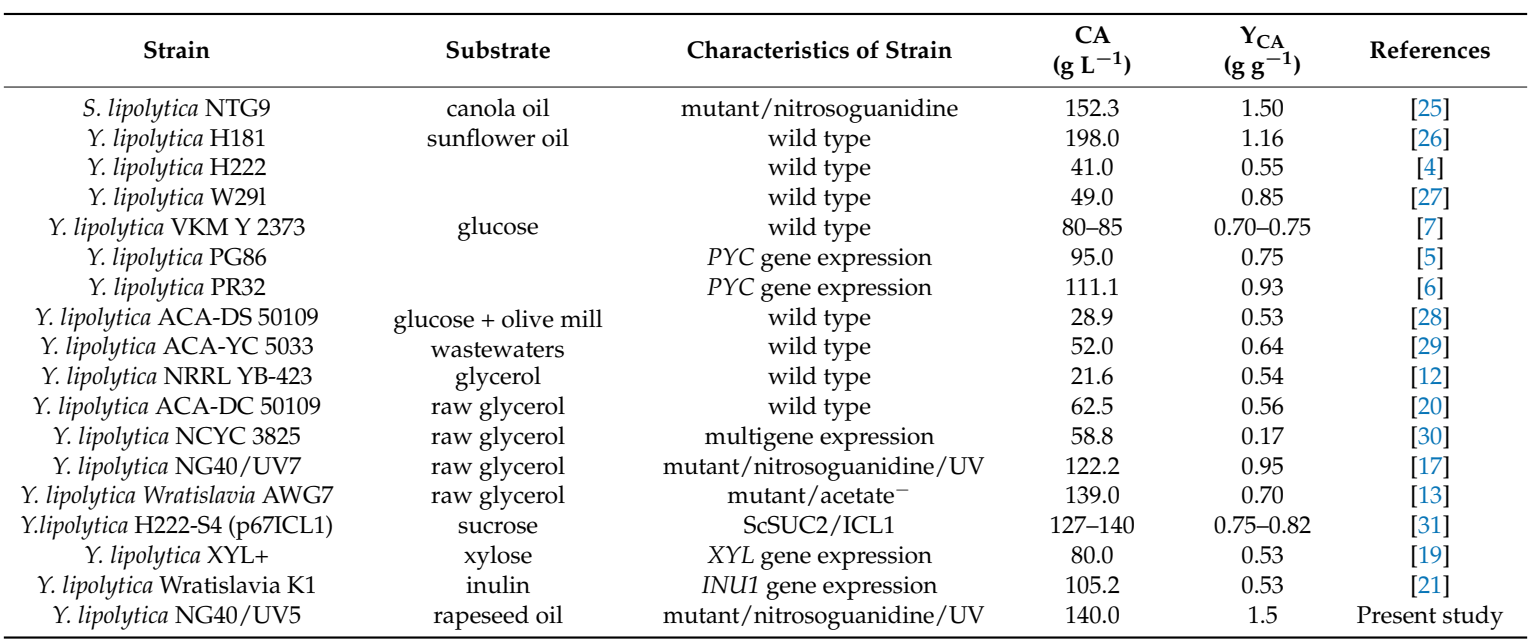

It should be noted that plant raw materials, such as wood, straw, and agricultural products processing waste, are inexpensive, accessible, renewable, and environmentally friendly substrates for microbiological synthesis of practically valuable compounds. However, the effective conversion of these substrates into easily assimilable carbohydrates (glucose, xylose, and higher glucose-containing polymers) is a difficult task. The traditional technologies of hydrolysis of plant raw materials with the use of strong acids and alkalis are associated with the formation of by-products that inhibit the growth of microorganisms and biosynthesis of target substances. Therefore, recombinant producers, effectively assimilating plant raw materials, were developed. For instance, Ledesmo-Amaro et al. (2016) engineered Y. lipolytica able to metabolize xylose to produce CA and lipids. The overexpression of xylose reductase, xylitol dehydrogenase and xylulokinase resulted in a production of $80 \mathrm{~g} \mathrm{~L}^{-1}$ of CA from xylose by mutant strain Y. lipolytica [19].

Rakicka et al. (2016) reported the production from inulin by engineered strain Y. lipolytica Wratislavia K1. The overexpression of the INU1 gene from Kluyveromyces marxianus coding inulinase resulted in the effective hydrolysis of inulin by mutant and the production of a high amount of CA (105.2 $\mathrm{g} \mathrm{L}^{-1}$ from $200 \mathrm{~g} \mathrm{~L}^{-1}$ inulin) [21].

\section{Conclusions}

The results of the experiments indicated that the mutant $Y$. lipolytica NG40/UV5 was able to grow and synthesize CA on media containing all types of the investigated renewable raw materials. However, it should be noted that the accumulation of the by-product of fermentation-ICA-was even very high in four of the six substrates investigated (glucose-containing aspen waste, glycerol, glycerol waste of biodiesel industry and ethanol). The best results were obtained using rapeseed oil (140 $\mathrm{g} \mathrm{L}^{-1}$ CA; CA:ICA ratio of 26.2:1; mass yield of CA production $\left(\mathrm{Y}_{\mathrm{CA}}\right)$ of $1.5 \mathrm{~g} \mathrm{~g}^{-1}$, and fermenter productivity of $\left.1.46 \mathrm{~g}(\mathrm{~L} \cdot \mathrm{h})^{-1}\right)$. However, economic considerations may lead to the fact that using a cheaper and less pure substrate (glycerol waste of biodiesel industry; $100 \mathrm{~g} \mathrm{~L}^{-1} \mathrm{CA}$; CA:ICA ratio of 7.7:1; mass yield of CA production $\left(\mathrm{Y}_{\mathrm{CA}}\right)$ of $0.9 \mathrm{~g} \mathrm{~g}^{-1}$, and fermenter productivity of $1.04 \mathrm{~g}(\mathrm{~L} \cdot \mathrm{h})^{-1}$ ) would be preferable on a production scale.

Author Contributions: I.G.M. conceived and designed the experiments, wrote the paper; S.V.K. and J.N.L. performed the experiments.

Funding: The reported study was funded by Russian Foundation for Basic Research (RFBR) according to the research project No. 16-08-00702.

Conflicts of Interest: The authors declare no conflict of interest. 


\section{References}

1. Cavallo, E.; Charreau, H.; Cerrutti, P.; Foresti, M.L. Yarrowia lipolytica: A model yeast for citric acid production. FEMS Yeast Res. 2017, 17. [CrossRef] [PubMed]

2. Anastassiadis, S.; Morgunov, I.G.; Kamzolova, S.V.; Finogenova, T.V. Citric acid production patent review. Recent Pat. Biotechnol. 2008, 2, 107-123. [CrossRef] [PubMed]

3. Finogenova, T.V.; Morgunov, I.G.; Kamzolova, S.V.; Chernyavskaya, O.G. Organic acid production by the yeast Yarrowia lipolytica: A review of prospects. Appl. Biochem. Microbiol. 2005, 41, 418-425. [CrossRef]

4. Moeller, L.; Strehlitz, B.; Aurich, A.; Zehnsdorf, A.; Bley, T. Optimization of citric acid production from glucose by Yarrowia lipolytica. Eng. Life Sci. 2007, 7, 504-511. [CrossRef]

5. Tan, M.J.; Chen, X.; Wang, Y.K.; Liu, G.L.; Chi, Z.M. Enhanced citric acid production by a yeast Yarrowia lipolytica over-expressing a pyruvate carboxylase gene. Bioprocess Biosyst. Eng. 2016, 39, 1289-1296. [CrossRef] [PubMed]

6. Fu, G.Y.; Lu, Y.; Chi, Z.; Liu, G.L.; Zhao, S.F.; Jiang, H.; Chi, Z.M. Cloning and characterization of a pyruvate carboxylase from Penicillium rubens and overexpression of the gene in the yeast Yarrowia lipolytica for enhanced citric acid production. Mar. Biotechnol. 2016, 18, 1-14. [CrossRef] [PubMed]

7. Kamzolova, S.V.; Morgunov, I.G. Metabolic peculiarities of the citric acid overproduction from glucose in yeasts Yarrowia lipolytica. Bioresour. Technol. 2017, 243, 433-440. [CrossRef] [PubMed]

8. Kamzolova, S.V.; Morgunov, I.G.; Aurich, A.; Perevoznikova, O.A.; Shishkanova, N.V.; Stottmeister, U.; Finogenova, T.V. Lipase secretion and citric acid production in Yarrowia lipolytica yeast grown on animal and vegetable fat. Food Technol. Biotechnol. 2005, 43, 113-122.

9. Kamzolova, S.V.; Lunina, J.N.; Morgunov, I.G. Biochemistry of citric acid production from rapeseed oil by Yarrowia lipolytica yeast. J. Am. Oil Chem. Soc. 2011, 88, 1965-1976. [CrossRef]

10. Aurich, A.; Specht, R.; Müller, R.A.; Stottmeister, U.; Yovkova, V.; Otto, C.; Holz, M.; Barth, G.; Heretsch, P.; Thomas, F.A.; et al. Microbiologically Produced Carboxylic Acids Used as Building Blocks in Organic Synthesis. In Reprogramming Microbial Metabolic Pathways; Wang, X., Chen, J., Quinn, P., Eds.; Springer: Dordrecht, The Netherlands, 2012; pp. 391-424. Available online: https://link.springer.com/chapter/10. 1007\%2F978-94-007-5055-5_19 (accessed on 28 September 2012).

11. Rymowicz, W.; Rywińska, A.; Żarowska, B.; Juszczyk, P. Citric acid production from raw glycerol by acetate mutants of Yarrowia lipolytica. Chem. Pap. 2006, 60, 391-395. [CrossRef]

12. Levinson, W.E.; Kurtzman, C.P.; Kuo, T.M. Characterization of Yarrowia lipolytica and related species for citric acid production from glycerol. Enzym. Microb. Technol. 2007, 41, 292-295. [CrossRef]

13. Rywińska, A.; Rymowicz, W.; Źarowska, B.; Wojtatowicz, M. Biosynthesis of citric acid from glycerol by acetate mutants of Yarrowia lipolytica in fed-batch fermentation. Food Technol. Biotechnol. 2009, 47, 1-6.

14. Makri, A.; Fakas, S.; Aggelis, G. Metabolic activities of biotechnological interest in Yarrowia lipolytica grown on glycerol in repeated batch cultures. Bioresour. Technol. 2010, 101, 2351-2358. [CrossRef] [PubMed]

15. Morgunov, I.G.; Kamzolova, S.V.; Lunina, J.N. The citric acid production from raw glycerol by Yarrowia lipolytica yeast and its regulation. Appl. Microbiol. Biotechnol. 2013, 97, 7387-7397. [CrossRef] [PubMed]

16. Rywinska, A.; Juszczyk, P.; Wojtatowicz, M.; Robak, M.; Lazar, Z.; Tomaszewska, L.; Rymowicz, W. Glycerol as a promising substrate for Yarrowia lipolytica biotechnological applications. Biomass Bioenergy 2013, 48, 148-166. [CrossRef]

17. Morgunov, I.G.; Kamzolova, S.V. Physiologo-biochemical characteristics of citrate-producing yeast Yarrowia lipolytica grown on glycerol-containing waste of biodiesel industry. Appl. Microbiol. Biotechnol. 2015, 99, 6443-6450. [CrossRef] [PubMed]

18. Wojtatowicz, M.; Rymowicz, W.; Kautola, H. Comparison of different strains of the yeast Yarrowia lipolytica for citric acid production from glucose hydrol. Appl. Biochem. Biotechnol. 1991, 31, 165-174. [CrossRef] [PubMed]

19. Ledesma-Amaro, R.; Lazar, Z.; Rakicka, M.; Guo, Z.; Fouchard, F.; Coq, A.C.; Nicaud, J.M. Metabolic engineering of Yarrowia lipolytica to produce chemicals and fuels from xylose. Metab. Eng. 2016, 38, 115-124. [CrossRef] [PubMed]

20. Papanikolaou, S.; Fakas, S.; Fick, M.; Chevalot, I.; Galiotou-Panayotou, M.; Komaitis, M.; Marc, I.; Aggelis, G. Biotechnological valorisation of raw glycerol discharged after biodiesel (fatty acid methyl-esters) manufacturing process: Production of 1,3-propanediol, citric acid and single oil. Biomass Bioengergy 2008, 32, 60-71. [CrossRef] 
21. Rakicka, M.; Lazar, Z.; Rywinska, A.; Rymowicz, W. Efficient utilization of inulin and glycerol as fermentation substrates in erythritol and citric acid production using expressing inulinase. Chem. Pap. 2016, 70, 1452-1459. [CrossRef]

22. Stephanopoulos, G. Challenges in engineering microbes for biofuels production. Science 2007, 315, 801-804. [CrossRef] [PubMed]

23. Weusthuis, R.A.; Aarts, J.M.M.J.G.; Sanders, J.P.M. From biofuel to bioproduct: Is bioethanol a suitable fermentation feedstock for synthesis of bulk chemicals? Biofuels Bioprod. Biorefin. 2011, 5, 486-494. [CrossRef]

24. Finogenova, T.V.; Puntus, I.F.; Kamzolova, S.V.; Lunina, I.N.; Monastyrskaia, S.E.; Morgunov, I.G.; Boronin, A.M. Obtaining of the mutant Yarrowia lipolytica strains producing citric acid from glucose. Prikl. Biokhimiia Mikrobiol. 2008, 44, 219-224.

25. Good, D.W.; Droniuk, R.; Lawford, R.G.; Fein, J.E. Isolation and characterization of a Saccharomycopsis lipolytica mutant showing increased production of citric acid from canola oil. Can. J. Microbiol. 1985, 31, 436-440. [CrossRef]

26. Aurich, A.; Förster, A.; Mauesberger, S.; Barth, G.; Stottmeister, U. Citric acid production from renewable resources by Yarrowia lipolytica. Biotechnol. Adv. 2003, 21, 454-455.

27. Papanikolaou, S.; Chatzifragkou, A.; Fakas, S.; Galiotou-Panayotou, M.; Komaitis, M.; Nicaud, J.M.; Aggelis, G. Biosynthesis of lipids and organic acids by Yarrowia lipolytica strains cultivated on glucose. Eur. J. Lipid Sci. Technol. 2009, 111, 1221-1232. [CrossRef]

28. Papanikolaou, S.; Galiotou-Panayotou, M.; Fakas, S.; Komaitis, M.; Aggelis, G. Citric acid production by Yarrowia lipolytica cultivated on olive-mill wastewater-based media. Bioresour. Technol. 2008, 99, 2419-2428. [CrossRef] [PubMed]

29. Sarris, D.; Stoforos, N.G.; Mallouchos, A.; Kookos, I.K.; Koutinas, A.A.; Aggelis, G.; Papanikolaou, S. Production of added-value metabolites by Yarrowia lipolytica growing in olive mill wastewater-based media under aseptic and non-aseptic conditions. Eng. Life Sci. 2017, 17, 695-709. [CrossRef]

30. Celińska, E.; Grajek, W. A novel multigene expression construct for modification of glycerol metabolism in Yarrowia lipolytica. Microb. Cell Fact. 2013, 12, 102. [CrossRef] [PubMed]

31. Förster, A.; Aurich, A.; Mauersberger, S.; Barth, G. Citric acid production from sucrose using a recombinant strain of the yeast Yarrowia lipolytica. Appl. Microbiol. Biotechnol. 2007, 75, 1409-1417. [CrossRef] [PubMed]

(C) 2018 by the authors. Licensee MDPI, Basel, Switzerland. This article is an open access article distributed under the terms and conditions of the Creative Commons Attribution (CC BY) license (http:/ / creativecommons.org/licenses/by/4.0/). 